\title{
Tree Swallows: A Nationwide Sentinel Species for Assessing and Monitoring Aquatic Contamination
}

Environmental contaminants are often the byproduct of industry and agriculture. United States Geological Survey (USGS) scientists provide information necessary to protect and restore our Nation's plants and animals from the effects of these contaminants. Federal and state management agencies use this information to determine if contamination has occurred and if any cleanup is necessary.

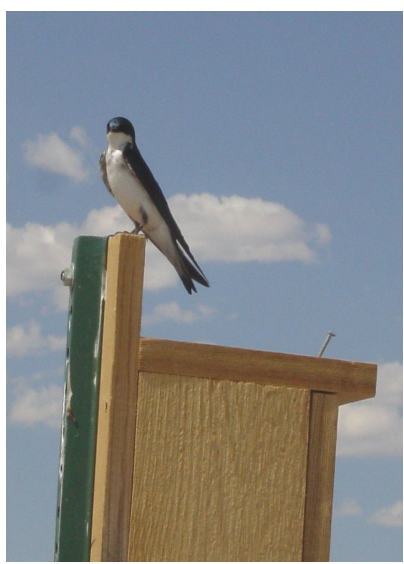

Tree swallow on nest box

Tree swallows are a useful bird species to measure exposure and effects of environmental contaminants: (1) They are widely distributed throughout the United States, (2) They will nest in boxes, so they can be attracted to study areas, and (3) They feed near their nest box on emergent aquatic insects. Aquatic insects emerge from river sediments, so the swallows' tissues reflect levels of contaminants in sediments.

Upper Midwest Environmental Sciences Center (UMESC) scientists study swallows in many locations across the United States to assist other government agencies with their contaminant concerns. Scientists evaluate exposure and effects of many contaminants including pesticides (for example, DDT), industrial contaminants (dioxins and PCBs), trace metals (lead and mercury), and petroleum.

Contaminant studies using swallows are often approached step-by-step. Generally, the first step is to find out if contaminants are in the environment and are found in

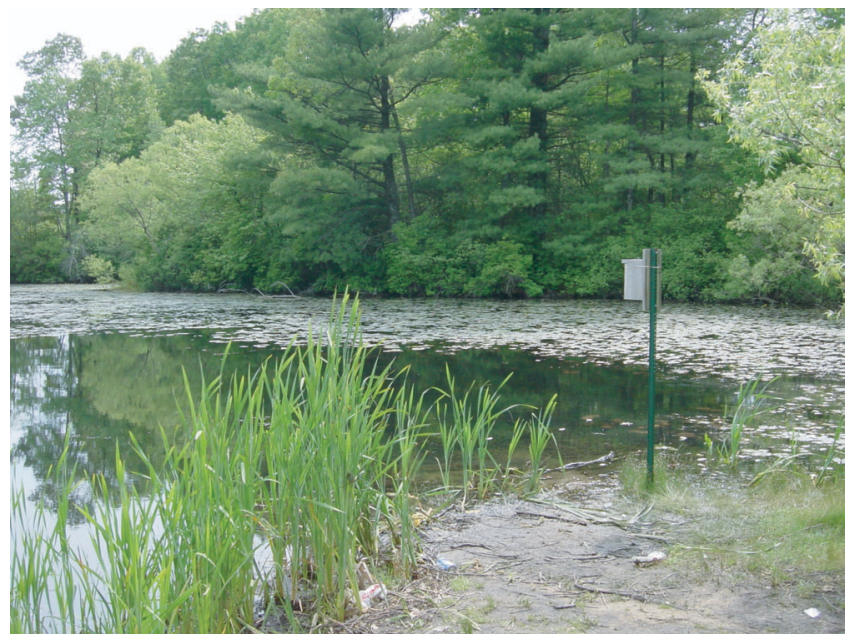

Nest box placed in typical tree swallow habitat

swallows. To do this, we analyze swallow eggs and other tissues for contaminants and compare them to uncontaminated locations. If contaminants are elevated in swallows, the next step is to find out if these contaminants affect tree swallow reproduction or survival. Many environmental contaminants are toxic to bird embryos, so we measure the number of eggs that hatch. We also measure the growth rate and survival of young. Because swallows tend to come back to where they nested the previous year, we can band them at their nest box and recapture adults in subsequent years. The percent of adult swallows that return the following year can be compared between contaminated and clean sites.

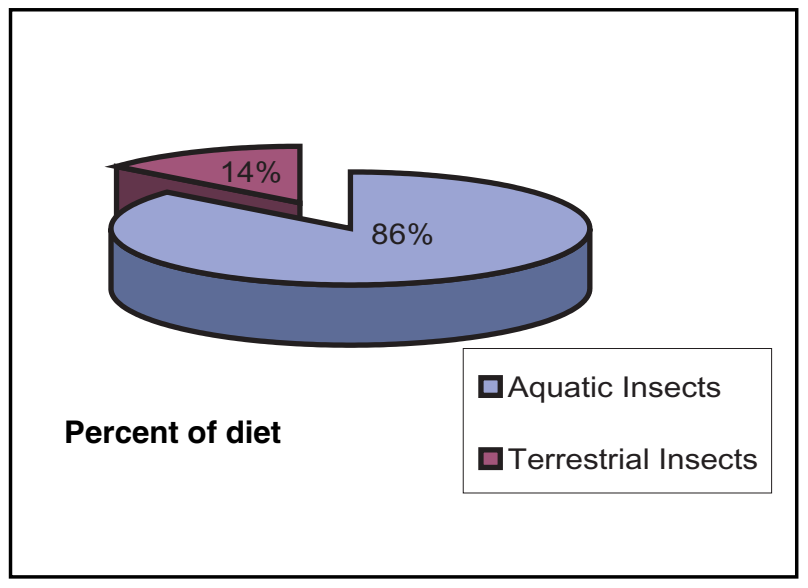

Typical tree swallow diet 


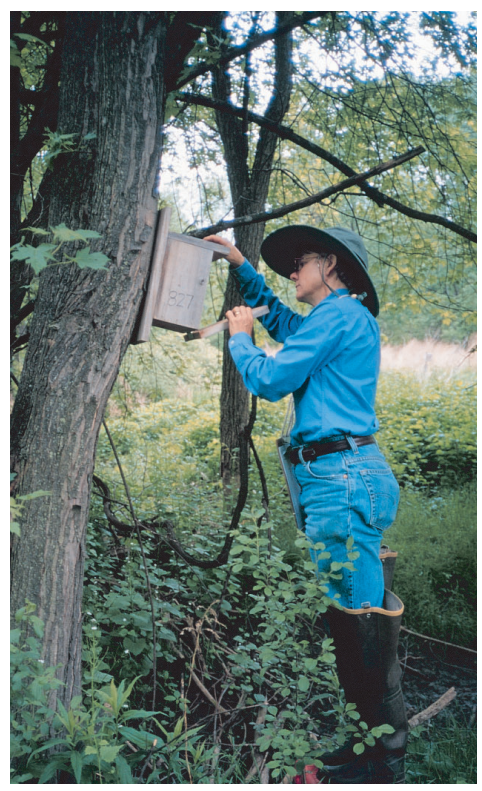

Scientist checking swallow nest box

Results from recent contaminant studies using tree swallows include the following:

$>$ Lead contamination from mining activities in the late 1800s along the Upper Arkansas River in Colorado is still inhibiting enzymes important to the functioning of red blood cells in tree swallows.

$>$ Hatching success of swallow eggs is lower on the highly contaminated Housatonic River in Massachusetts as a result of industrial pollution.

$>$ Severe hatching problems are occurring at a site in Rhode Island that has some of the highest dioxin concentrations ever reported in tree swallow eggs.

$>$ Petroleum contamination was not detected in swallows at a former oil refinery site in central Wyoming and we did not recommend cleanup.

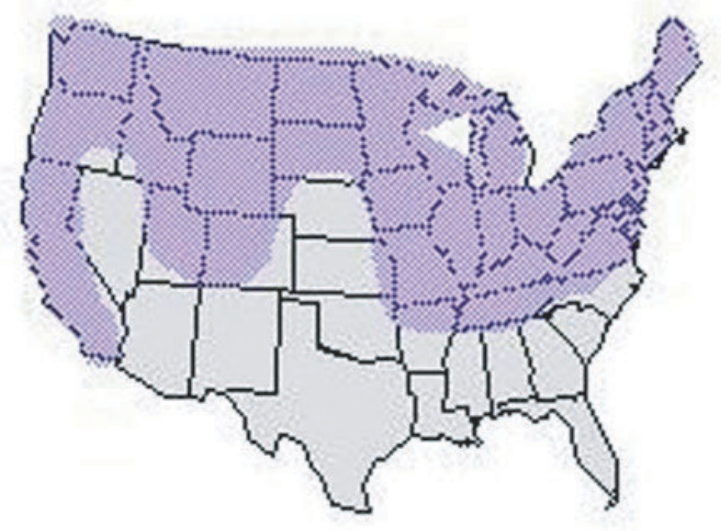

Tree swallow distribution across the United States

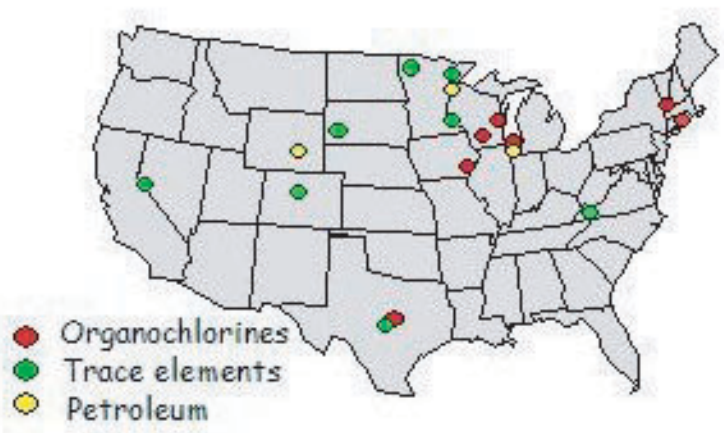

Location of swallow study sites by Upper Midwest Environmental Sciences Center scientists

The U.S. Fish and Wildlife Service, U.S. Environmental Protection Agency, and state agencies continue to request assistance from UMESC. The agencies use results like these to make decisions regarding our Nation's environment.

\section{For more information, contact -}

Christine Custer

608.781 .6247

ccuster@usgs.gov

Thomas Custer

608.781.6375

tcuster@usgs.gov

USGS Upper Midwest Environmental Sciences Center 2630 Fanta Reed Road

La Crosse, WI 54603

\section{http://www.umesc.usgs.gov/}

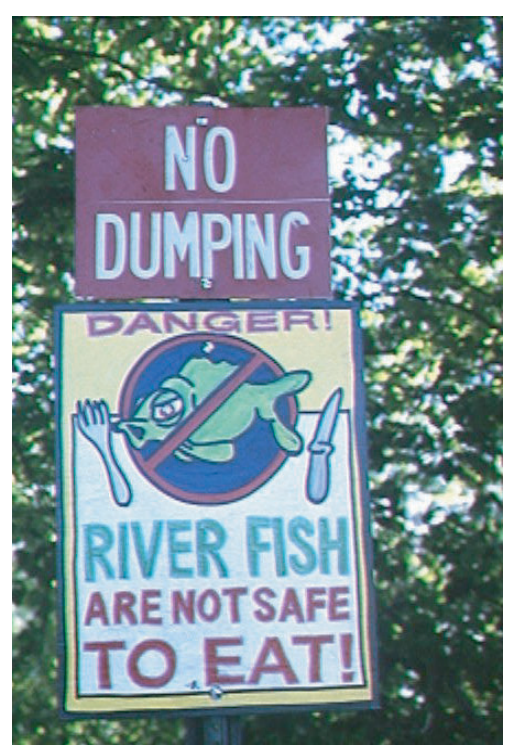

Warning sign 